\title{
Naturalismo, pornografia e histeria em Mártires da virgindade, de Alfredo Gallis
}

\author{
Aline Moreira Duarte ${ }^{1}$ \\ Universidade do Estado do Rio de Janeiro
}

Resumo: Este artigo propõe uma leitura da obra Mártires da virgindade (c.1900), do escritor português Joaquim Alfredo Gallis (1859-1910), de modo a explorar o tema da histeria na literatura naturalista. A fim de fundamentar a análise, buscamos observar de que maneira a pornografia e o naturalismo se confundiam na virada do século, na medida em que o sexo, em pleno burburinho positivista, parecia ser uma causa das mazelas físicas e mentais - as chamadas "patologias sociais" da sociedade do período.

Palavras-chave: Alfredo Gallis. Mártires da Virgindade. Naturalismo. Pornografia. Histeria.

Essas insônias, fastios, pesadelos, sonolências, irritações nervosas, delíquios, esmorecimentos de ânimo, dores nos ovários e nos hipocôndrios, ataques de raiva e choro, aborrecimento constante, e mais misérias que torturam milhares de raparigas solteiras, não são mais nem menos do que a consequência do celibato forçado. (...) A mulher celibatária, na rigorosa acepção do termo, é o ente mais desgraçado que conheço.

Alfredo Gallis

\section{Introdução}

O trecho que compõe a epígrafe do trabalho aparece no proêmio do romance naturalista Mártires da virgindade, publicado em Lisboa por volta de 1900, do escritor esquecido Joaquim Alfredo Gallis (1859-1910). Ainda sabemos pouco sobre ele. Quando morreu, o crítico português José Agostinho escreveu que o escritor seria "mais estimável se não se tivesse manchado em várias obras pornográficas" (AGOSTINHO apud VENTURA, 2011, p. 167). Apesar da reputação de autor pornográfico e do seu esquecimento, estudos recentes, como os da pesquisadora brasileira Alessandra El Far, revelam que Alfredo Gallis foi um autor popular no seu tempo, em especial no Brasil, justamente por seus escritos anunciados como "leitura quente" (EL FAR, 2004, p. 244) - expressão usada na época para se referir à

\footnotetext{
${ }^{1}$ Pós-graduada em Estudos Literários pela Universidade do Estado do Rio de Janeiro (2015) e graduada em Letras (Português/Literaturas) pela Universidade Veiga de Almeida (2013). SOLETRAS - Revista do Departamento de Letras da FFP/UERJ 
literatura licenciosa. Escritor produtivo, Alfredo Gallis fez amplo uso da temática sexual, criando narrativas que descreviam com realismo o ato sexual e o prazer dos personagens, além de outras que evidenciavam, como se dizia na época em vocabulário condenatório, taras, "vícios" ou "perversões libertinas".

Gallis não escrevia apenas para incitar o prazer do leitor, mas também para estudar e denunciar. As obras naturalistas pretendiam pôr a nu a vida íntima da burguesia portuguesa, revelando "as mazelas de uma sociedade repleta de imoralidades" (EL FAR, 2004, p. 245). Mártires da virgindade é um dos romances naturalistas que Gallis escreveu como forma de denúncia. O proêmio explicava ser o objetivo da obra "apresentar, ao vivo, uma das mais monstruosas violências do nosso tempo" (GALLIS, s. d., p. 17): o celibato forçado da mulher fora do casamento. Servindo-se de termos científicos e de estilo panfletário, Alfredo Gallis propõe uma discussão acerca da privação sexual forçada que levava muitas mulheres, quando não à morte, à loucura. Chamava-se tal condição de "histeria feminina" - um tema que animou a pena de inúmeros escritores do século XIX, como Gustave Flaubert (1821-1880) em Madame Bovary (1857), Eça de Queirós (1845-1900) em O primo Basílio (1878), Aluísio Azevedo (1857-1913) em O homem (1887) e Júlio Ribeiro (1845-1890) em A carne (1888).

Como veremos na descrição da protagonista Maria Manuela, o discurso do desejo e da sexualidade femininos reproduzia o estereótipo da mulher hipersexualizada. Tal caráter fazia com que esse tipo de ficção naturalista fosse rotineiramente confundido com literatura pornográfica (MENDES, 2014), e assim foi com Mártires da virgindade. É nesse sentido que, pondo de lado o rótulo de "imorais" a que a crítica da época reduziu a obra e seu autor, condenando-os ao esquecimento, este artigo volta-se para a leitura de Mártires da virgindade com a intenção de compreender de que maneira literatura e ciência se aliavam em finais do século XIX, e como o escritor português explorou a interface entre a ficção naturalista e a literatura pornográfica, na medida em que ambas se apresentavam como um discurso materialista sobre o corpo e os impulsos sexuais.

\section{Alfredo Gallis: um ilustre desconhecido}

São limitadas as informações biográficas sobre Alfredo Gallis. Ao contrário de muitos escritores contemporâneos, ele é quase um desconhecido para os estudiosos do século XXI; o autor não é lembrado pela história da literatura e tampouco possui um lugar no rol dos escritores naturalistas em língua portuguesa. Entretanto, essa realidade está mudando, haja 
vista as pesquisas realizadas nos últimos anos que buscam recuperar autores e obras que, por seu caráter subversivo ou popular, foram esquecidos pela crítica.

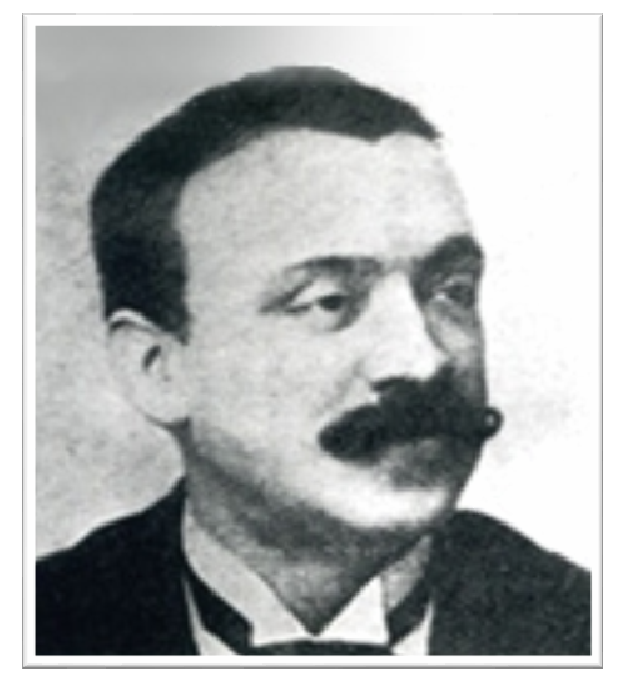

Fig. 1: Joaquim Alfredo Gallis (1859-1910)

Fonte: Site Vinculados ao Barreiro.

Até onde a pesquisa pôde constatar, há apenas dois trabalhos publicados, ambos portugueses, sobre a vida e a obra de Alfredo Gallis: o artigo "Pornografia no fim do século: os romances de Alfredo Gallis" (2004), da professora portuguesa Maria Helena Santana, da Universidade de Coimbra; e o posfácio "Rabelais, isto é, Alfredo Gallis, o pornógrafo", escrito por Antonio Ventura para o livro Aventuras Galantes (2011), que faz parte da coleção "Livros Licenciosos" da Edições Tinta da China, de Lisboa. De acordo com Santana, "Gallis foi um novelista prolífico" que publicou "mais de três dezenas de títulos, distribuídos numa escala descendente que abrange desde obras de índole mais ou menos respeitável, até as mais desqualificadas"; e foi exatamente sua tendência à literatura de "baixa índole" que fez com que o autor permanecesse "praticamente desconhecido da Crítica e ainda hoje [seja] mais fácil encontrá-lo nos alfarrabistas do que nas bibliotecas" (SANTANA, 2004, p. 240). Sua impressionante popularidade no final do século XIX, segundo a autora, "não se explica pela qualidade literária - que não tem -, mas decerto pela falta de concorrência, dado que apenas a novela francesa alimentava o mercado da literatura erótica da época" (SANTANA, 2004, p. 240). Os dados fornecidos por Ventura não são diferentes. O crítico ressalta que "nos finais do século XIX sucederam-se as publicações de cariz licencioso" e que "Rabelais", pseudônimo mais famoso de Gallis, foi o mais "prolífero de todos os autores dessa época" (VENTURA, 2011, p. 167-168). 
Apesar da nacionalidade portuguesa, são as informações contidas em artigos publicados nos jornais brasileiros da virada do século XIX para o XX que nos permitem ter uma noção mais ampla da grande fama que Gallis possuía como escritor pornográfico. No Brasil, seu pseudônimo "Rabelais" era um dos mais conhecidos entre os leitores das chamadas "obras imorais" que enchiam as estantes das livrarias populares no Rio de Janeiro. Segundo El Far, muitas livrarias possuíam uma categoria chamada de "Obras de Rabelais" (EL FAR, 2004, p. 203), e isso é apenas um dos indícios da popularidade do escritor no Brasil. Produzidas em formato de brochuras de baixo custo, essas obras eram vendidas a preços populares - entre $2 \mathrm{e}$ 3 mil réis -, mas as grandes tiragens necessárias para suprir a demanda dos ávidos leitores eram suficientes para garantir o lucro dos livreiros. Qualquer associação ao pseudônimo funcionava como garantia de boas vendas. Pedro Quaresma, proprietário da Livraria do Povo e um dos mais importantes livreiros brasileiros do final do século XIX e início do XX (LEÃO, 2012), valia-se dessa associação ao anunciar o livro Os crimes do amor, de "Rabelais". Num panfleto de divulgação de livros à venda na livraria, Quaresma fazia a promessa de uma "Leitura quente!!!", composta de "mistérios e iniquidades", reforçando que se tratava de um livro do "apreciado, procurado e adorado Rabelais", a quem o livreiro chama de "imortal" (EL FAR, 2004, ilustração 27).

Gallis lucrou com a popularização do livro na virada do século, tanto em Portugal quanto no Brasil, graças a um mercado livreiro interessado em atrair um público consumidor de "volumes de baixo custo e das chamadas coleções populares" (EL FAR, 2004, p. 51). Esse dado nos é caro, visto que, ao acentuar a vulgarização da leitura, contradiz o lugar-comum da historiografia literária de que ninguém lia no Brasil. Como declara El Far, foi na medida em que o livro se impôs como mercadoria a partir de 1880 que as obras começaram a surgir com maior diversidade de conteúdo e forma, dando lugar a "exemplares mais baratos e de fácil comercialização" (EL FAR, 2004, p. 54).

Outro registro da notoriedade de Gallis pode ser encontrado num dos livros mais populares daquele fim de século, $O$ aborto (1893), de Alberto Figueiredo Pimentel (18691914) (CATHARINA, 2013). Romance naturalista que, como Mártires da virgindade, flerta com o gênero pornográfico, $O$ aborto narrava o "relacionamento indecoroso" entre primos, o estudante Mário e a espevitada Maricota, que, contrariando a rígida moral da sociedade oitocentista, experimentam, fora do casamento, as descobertas do desejo sexual. Em um baú secreto, Mário guardava romances naturalistas escandalosos, como "O homem, de Aluísio Azevedo; O crime do padre Amaro, de Eça de Queirós; Esposa e virgem, de Belot; Nana, de SOLETRAS - Revista do Departamento de Letras da FFP/UERJ

Número 30 (jul.-dez 2015)

ISSN: 2316-8838

DOI: http://dx.doi.org/10.12957/soletras.2015.18530 
Emílio Zola; as Volúpias de Rabelais; e mais outros" (PIMENTEL, 2015, p. 72). Ao encontrar a pequena biblioteca proibida às mulheres, Maricota aprende, às escondidas, "coisas completamente ignoradas, e reparando em vários episódios que não compreendia bem, mas onde pressentia grandes imoralidades" (PIMENTEL, 2015, p. 72).

A menção de uma das obras licenciosas mais populares de Gallis num romance também popular e licencioso nos revela que a ficção naturalista, mesmo a mais celebrada pela historiografia (como os romances de Zola e Eça de Queirós), era lida como forma de entretenimento pornográfico, "somente pelo lado da bandalheira" (PIMENTEL, 2015, p. 72). A aparição de "Rabelais" no romance de Figueiredo Pimentel nos fornece um documento histórico irrefutável, ampliando o nosso entendimento a respeito da fama espetacular que Alfredo Gallis possuía em vida, guardado ao lado de Zola e Eça de Queirós nos baús de casas de família e autor em demanda nas livrarias populares.

\section{Sobre naturalismo, patologia social, pornografia e histeria}

Surgida na França na segunda metade do século XIX, a ficção naturalista era um tipo de romance realista que se aliava ao novo discurso científico para expressar literariamente a crença materialista na irrefreável força do mundo físico frente às convenções sociais e religiosas. O romance naturalista apresentava teses científico-literárias que podiam ser a favor ou contra da liberação dessa força. O desejo sexual era uma representação especialmente interessante, posto que problemática, para a exploração das teses naturalistas. O sexo e o erotismo eram "um gerador poderosíssimo do interesse narrativo" (SANTANA, 2004, p. 238) e chamarizes de editores dispostos a editar os romances naturalistas e de leitores interessados em comprá-los e lê-los.

Alguns romances naturalistas viam o mundo físico como um mal a ser debelado, como fator de dissolução dos costumes e ataque à moral civilizadora. Seu objetivo era, então, revelar, estudar e denunciar esses males. Esses livros pertenciam a um subgênero do naturalismo que veio a ser conhecido como "romances de patologia social". Em Portugal, o escritor Abel Botelho (1854-1917) publicou cinco romances naturalistas - O Barão de Lavos (1891), O Livro de Alda (1898), Amanhã (1901), Fatal Dilema (1907) e Próspero Fortuna (1910) - numa série que ele chamou de "Patologia Social". Alfredo Gallis executou feito semelhante em sua Tuberculose social, série cuja primeira das doze obras tinha o título de Chibos, indicando o propósito de "chibar", ou seja, delatar as mazelas sociais. Eram romances 
de investigação e denúncia, que se apropriavam dos termos "patologia" ou "patológico", oriundos da biologia, para explorar e comprovar a crença naturalista de que a sociedade era impotente ante a natureza.

Entre as patologias sociais representadas nos romances naturalistas, aquelas ligadas ao sexo apareciam com bastante predominância. Os romances apresentavam casos de relações sexuais escandalosas para a época, entre as quais estavam o adultério, o incesto, a prostituição, a ninfomania, a pederastia e a sodomia (termos então usados para se referir à homossexualidade), e outros tipos de comportamentos tidos então por imorais, posto que eram estabelecidos além do sagrado ambiente do matrimônio. Sua prática se configurava como uma ofensa aos bons costumes.

No imaginário oitocentista, a mulher era vista como um agente das forças naturais que devia ser controlado. Mesmo que fossem evidentes as mudanças que permitiram à mulher assumir novos papéis ao longo do século XIX, o estigma da submissão estava longe de ser superado. A fragilidade a que a mulher era associada a tornava dependente da figura masculina. Por isso seus passos eram controlados por demandas sociais que regiam, acima de todas as coisas, a sexualidade feminina. Como resultado, começaram a aparecer mulheres que sofriam por causa da repressão sexual, no que se diagnosticava então como "histeria". Derivada do grego histéra (útero), a histeria era tão comum que a mulher era considerada um ser "doente" por natureza, "essencialmente caracterizada por certo histerismo, que se pode apresentar em diversos graus, mas que assume sempre conotações de âmbito sexual (...)" (JESUS, 1998, p. 154).

O tema da histeria é antigo, remontando à Antiga Grécia, mas foi a voga científica e pedagógica do século XIX que transformou a histeria num assunto importante. Os avanços nos estudos fisiológicos e psicológicos permitiram aos médicos analisar e tratar da histeria muito antes que Sigmund Freud (1856-1939) e a Psicanálise se tornassem referência no assunto. O que na Idade Média chegou a ser considerado como "possessão diabólica" (RANGEL, 2008, p. 59), Jean-Martin Charcot (1825-1893), de quem Freud foi discípulo, descobriu tratar-se de uma "doença mental" com variados sintomas psíquicos e físicos, dentre os quais desmaios, prostração e "acessos dramáticos". Acreditava-se também que a histeria era causada por um sistema neurológico fraco e suscetível à influência hereditária.

Como não poderia ser diferente, as histéricas, mesmo não tendo culpa de sua condição, eram estigmatizadas socialmente. Numa sociedade patriarcal, a sexualidade problemática que se manifestava não apenas em jovens solteiras, mas também em senhoras casadas de índole SOLETRAS - Revista do Departamento de Letras da FFP/UERJ

Número 30 (jul.-dez 2015)

ISSN: 2316-8838

DOI: http://dx.doi.org/10.12957/soletras.2015.18530 
"respeitável”, corroborou a imagem da mulher como ente frágil e suscetível aos perigos do sexo. Nesse sentido, mesmo com as opções de tratamento, as condições sociais ainda eram opressivas e discriminadoras. Por isso "praticamente todas as heroínas naturalistas possuem temperamento nervoso" e "os nervos [eram], assim, o principal signo da mulher e do sexo" (JESUS, 1998, p. 154).

Para o romance naturalista, a histeria era naturalmente um tema promissor e explosivo. Mirando nas hipocrisias da vida burguesa, os livros denunciavam a repressão sexual comandada pela rigidez de padrões morais inalcançáveis. Em se tratando de uma classe social que culpabilizou a liberdade, não espanta a presença constante - às vezes maçante - de personagens histéricas em romances naturalistas. Essas obras, afirma Bulhões, “expõem as marcas do conflito entre o campo das pulsões sexuais e o das proibições da civilização, o qual se traduz em sensações torturadas e no mal-estar que as personagens tragicamente carregam" (BULHÕES, 2005, p. 7). Apropriadas como literatura pornográfica pelo leitor do século XIX, essas e outras obras naturalistas denunciavam a violência contra a mulher, especialmente por lhe negar autonomia sobre o próprio corpo. Por isso, foram condenadas por imorais, quando não eram mais do que o retrato da sociedade. Era natural que a sociedade viesse a temer os efeitos que esse tipo de leitura pudesse provocar nas jovens de índole "frágil".

O uso do sexo como ferramenta reveladora dos "males" da sociedade é ainda mais antigo. Havia na Europa, desde o século XVI, uma tradição literária de caráter fundamentalmente contestatório que usava o discurso licencioso como forma de atacar as autoridades políticas e religiosas. Conquanto fosse antiga e bastante comum, apenas no final do século XVIII e o início do XIX foi estabelecida a concepção moderna de pornografia como produção artística (HUNT, 1999). O tema, por sua vez, não deixa de ser problemático, visto que a classificação de uma obra como "pornográfica" segue critérios subjetivos. Segundo Dominique Maingueneau, "a depender dos lugares e dos momentos, o rótulo 'pornográfico' foi atribuído a produções que, em outros tempos ou em outros lugares, certamente não seriam listadas nessa categoria" (MAINGUENEAU, 2010, p. 14).

Ambos publicados em 1857, As flores do mal, de Charles Baudelaire (1821-1867), e Madame Bovary, de Gustave Flaubert (1821-1880), são exemplos de obras que, com o passar do tempo, contrariando as acusações que receberam na época da publicação, deixaram de ser consideradas pornográficas. Maingueneau afirma que, "por natureza, a literatura pornográfica está destinada à proibição" (MAINGUENEAU, 2010, p. 15), e que essa interdição dificulta a classificação das obras. Portanto, o romance naturalista foi incorporado à tradição da literatura SOLETRAS - Revista do Departamento de Letras da FFP/UERJ 
licenciosa devido ao consumo pornográfico de que era objeto pelo leitor do século XIX, ainda que seu principal objetivo fosse, a crer nas declarações de seus autores, tratar de outros temas, como ciência e política.

Em sua maioria, as obras naturalistas foram acusadas de pornográficas - ou pelo menos de eróticas -, mas dificilmente tratavam do sexo da maneira explícita que hoje associamos aos termos. Usados às vezes como sinônimos, termos como erótico e pornográfico possuem atualmente pesos morais e estéticos diferentes. O erotismo seria uma representação velada e esteticamente elaborada do sexo; um processo que "mostra e mascara ao mesmo tempo", pois “evoca uma cena que poderia ser pornográfica se não tivesse sido transformada em espetáculo estetizante" (MAINGUENEAU, 2010, p. 37). Já a pornografia, ao contrário, atua no universo da transparência e da representação da cena sem pudores ou aspirações estéticas. $\mathrm{O}$ leitor/espectador de uma cena de temática sexual, no erotismo, seria chamado de "contemplador", como quem está diante de apenas mais uma representação artística; na pornografia, ele seria um voyeur, convidado a participar, mesmo que à distância, de algo ilícito.

Nem sempre essa conceituação é suficiente para compreender o fenômeno da tradição pornográfica do século XIX, quando a rígida moral burguesa classificava como "pornográfica" qualquer literatura que ofendesse os bons costumes, mesmo aquela que versasse sobre o sexo reprimido, como as ficções sobre a histeria. Romances naturalistas como $O$ crime do padre Amaro e $O$ aborto, entre outros, foram acusados de pornográficos e imorais em seu tempo, mas pouco tinham de "sexo de fato" para um leitor do século XXI. Pode-se dizer que grande parte dessas obras, considerando a definiçãa de Maingueneau, seriam para nós mais eróticas do que pornográficas, visto que a relação sexual era apenas um dos acontecimentos da narrativa, mais uma das várias áreas da vida humana analisadas pelo microscópio naturalista.

A representação literária da mulher hipersexualizada, mesmo que gerasse incômodo, também revelava um olhar opressor ao patentear uma condição patológica como a única maneira de se tratar do desejo feminino. De acordo com Verona (2008), "não faltam exemplos demonstrando o que os escritores do século XIX entendiam por "natureza feminina"'. Além do caso de Emma Bovary, podemos citar também os ataques histéricos da portuguesa Luísa, de $O$ primo Basílio, que, como sua predecessora francesa, era uma jovem de arroubos e extravagâncias românticas que a levaram do tédio ao adultério; outro exemplo é a Magdá, de 
$O$ homem, que estava sempre prostrada a cismar e a delirar fantasias eróticas que jamais realizaria.

Esses e outros são exemplos da caracterização da mulher como ser frágil, um ser cuja plena satisfação somente o casamento e maternidade conferiam. Verona afirma ser "sempre comum às protagonistas (...) um sorriso pálido, uma mão trêmula, uma melancolia, um desmaio, um abatimento, uma volubilidade nervosa, um gesto convulso, uma febre intensa, um delírio, uma síncope” (VERONA, 2008, p. 6), todos efeitos da frustração. Cheias de ressentimento e tomadas por uma insatisfação crônica, emocional ou sexual, restava a essas personagens apenas a fatídica morte. Primeiro, a lenta morte de sua sonhada felicidade ante a inexorabilidade das normas sociais que lhe obrigavam a adiar o prazer sexual, até que o corpo viesse a sucumbir, finalmente, num leito de dor, miséria e sofrimento.

\section{Mártires da virgindade: romance patológico}

A associação com o martírio fica clara no longo proêmio de Mártires da virgindade, em que o autor afirma ter a intenção de "abordar um dos mais complexos e interessantes problemas de todos os tempos: o celibato forçado da mulher, imposto pelo convencionalismo e egoísmo sociais" (GALLIS, s. d., p. 8). O Autor - como refere a si mesmo no final do proêmio - se mostra comprometido com a luta pela autonomia sexual feminina e, muitas vezes, parece um perfeito defensor das causas feministas.

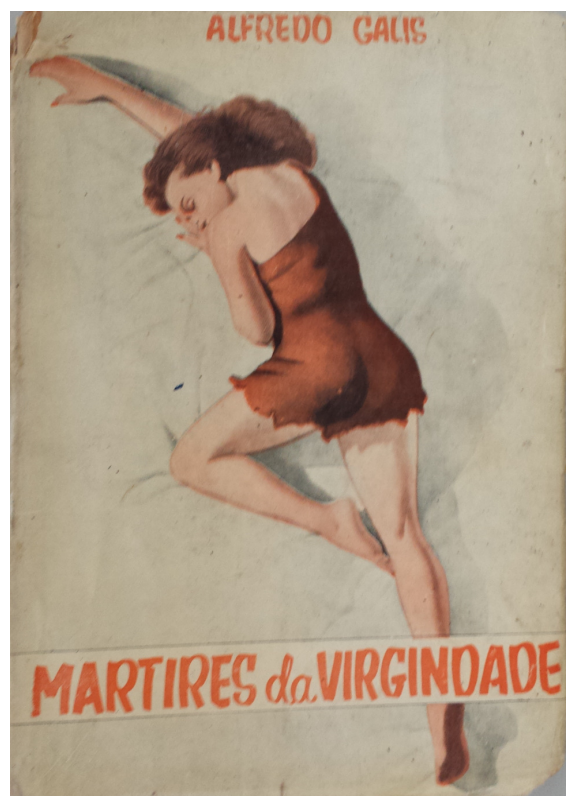

Fig. 2: Capa do exemplar consultado na pesquisa

Fonte: Acervo pessoal.

SOLETRAS - Revista do Departamento de Letras da FFP/UERJ

Número 30 (jul.-dez 2015)

ISSN: 2316-8838

DOI: http://dx.doi.org/10.12957/soletras.2015.18530 
O proêmio é repleto de casos de histeria que o Autor garante serem verídicos. Ele se refere aos médicos "que estão fartos de reconhecer casos da doença" (GALLIS, s. d., p. 9) e cita o episódio em que o "celebrado Dr. Brilhante, original médico homeopata, que foi famoso em Lisboa", foi chamado por "um pai aflito para tratar da filha anêmica e nervosa, em estado grave”, receitando o matrimônio como única opção de tratamento: “- Olhe, case-a, case-a que só o casar... a pode curar!" (GALLIS, s. d., p. 9). O Autor também fala do caso da filha de um amigo, que teria passado meses "entre a vida e a morte, num estado de fraqueza enorme e quase paralítica do lado direito", até que a gravidez a salvou (GALLIS, s. d., p. 10).

Todos esses elementos revelam como Gallis estava afinado com os assuntos médicos e científicos de sua época. Em termos cronológicos, já vimos que o autor foi contemporâneo dos estudos de Charcot e Freud, e não seria absurdo dizer que foi da leitura desses e outros autores que o português tirou seus argumentos. Assim, apresenta casos de mortes e de jovens doentes como efeitos do histerismo, que nada mais eram do que o sofrimento causado pela interdição e culpabilização do desejo feminino. Nas palavras do Autor, "a mulher celibatária, na rigorosa acepção do têrmo, é o ente mais desgraçado que conheço, se êsse celibato não provém do seu temperamento, mas sim de causas e circunstâncias que a isso a forçaram" (GALLIS, s. d., p. 11). A sociedade patriarcal era o algoz dessas mártires que "não têm culpa alguma desta crueldade" masculina de estigmatizar e menosprezar "a mulher solteira que disponha do seu corpo como melhor entender" (GALLIS, s. d., p. 11).

Como seus contemporâneos naturalistas, Gallis se isentava de eventuais acusações de imoralidade, afirmando que não pretende

[...] atirar às faces do público com um pregão contra a dissolvência dos costumes, mas única e exclusivamente autopsiar fatos de todos os dias, passados no mistério profundo da vida das famílias, e terminados no ato triste e banal do lançamento de caixões à cova, onde se dá por terminada a trágica comédia da humanidade (GALLIS, s. d., p. 17).

Seu objetivo é "apresentar, ao vivo, uma das mais monstruosas violências dos nossos tempos, qual a de negar à fêmea, sob o risco de desonra, o exercício legal de satisfazer as exigências fisiológicas do seu sexo" (GALLIS, s. d., p. 17). Negar esse direito à mulher sem marido era sinal de que "essa civilização encontra[va]-se em positiva falência, vendo-se na necessidade de ir buscar em sofismas capciosos o que deveria manter em ampla e bem definida liberdade" (GALLIS, s. d., p. 17).

O Autor conclui o proêmio afirmando que "a sociedade não tem direito algum de impor à mulher a virgindade forçada, repudiando-a quando ela oferece essa virgindade no pleno 
direito de dispor de seu corpo e da sua alma como bem entender e quiser", e revela seu repúdio à "farsa matrimonial" (GALLIS, s. d., p. 18), esse que era o único meio pelo qual a mulher podia conseguir algum respeito. Ele também adverte ao leitor que "essa restrição produz enfermidade e cadáveres", como passará a expor na narrativa, e que a permanência dessa opressão é, "na prática, um crime hediondo" (GALLIS, s. d., p. 18).

Para dar provas da tese, ao proêmio segue a história de Maria Manuela, uma jovem de vinte e cinco anos que possuía reputação impecável, mas escondia "uma carne sensível e ardente, que tantas vezes boiara à superfície do azulado sonho dos prazeres do amor", algo que, em sua falta de experiência, ela mal compreendia. Dotada de um espírito triste, resultante da morte do pai, da doença da mãe e da partida do irmão mais velho, apenas aos vinte e três anos Maria Manuela viu florescer "na sua alma reservada e pura" os primeiros indícios do amor. Fora o Luís, com seu "talhe esbelto e gentil", e "seus olhos negros, cismadores e ternos”, a causa dessa mudança (GALLIS, s.d., p. 22).

Em seu "organismo sensível”, com apenas os simples beijos que o namorado lhe dava nas mãos, Maria era acometida por "um deleitoso prazer sexual acompanhado de um esgotamento fluído que a enfraquecia bastante" (GALLIS, s. d., p. 23). É notável que o vocabulário do narrador rejeita metáforas românticas que pudessem aliviar para o leitor a descrição do desejo sexual. Ao contrário, a narrativa traz expressões que evidenciam certa crueza, uma vez que os efeitos da excitação sexual da personagem não são mentais, mas fisiológicos. O narrador, então, fala de "impressão fisiológica", de "fibras nervosas", uma "sensação esquisita na espinha dorsal" e uma "grande frouxidão nas curvas das pernas" (GALLIS, s. d., p. 23). A leitura que fazemos hoje, no século XXI, caracteriza esse tipo de passagem como "naturalista", e não como "pornográfica", mas imaginemos a recepção dessas palavras no contexto da sociedade recém-saída do século XIX; para aquele leitor, acostumado a reprimir suas emoções e sensações físicas, esse tipo de descrição causava grande comoção e liberação.

Ao contrário de Maria Manuela, o Luis não era afetado da mesma maneira. Enquanto Maria via nele o marido ideal, pressentindo que "havia de ser muito feliz sendo espôsa do cavalheiro de tão lídimas qualidades" (GALLIS, s. d., p. 26), Luis aproximara-se da jovem porque tinham-lhe dito que, com a morte da mãe, Maria "herdaria uma fortuna regular". Malicioso e experiente, tomara o cuidado de nunca falar em casamento para se manter livre de qualquer compromisso, mas tinha plena consciência do "grande abalo fisiológico" que os beijos causavam "no organismo da pobre rapariga” (GALLIS, s. d., p. 27).

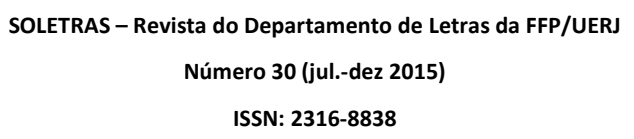


Deixando claras as intenções de Luis, o narrador evidencia a força da "alma sensível e apaixonada de Maria" (GALLIS, s. d., p. 28). Os sonhos de um amor ideal, além da excitação sexual que a moça sentia, eram fruto de sua "carne voluptuosa", e não de reais investidas do namorado. Em diversas passagens, o leitor toma conhecimento da profundidade do desejo de Maria Manuela:

Nas suas longas e repetidas noites de insônia tinha-o [Luís] sempre a seu lado, e então, nesse profundo mistério da imaginação humana, beijava-o, abraçava-o, apertava-o de encontro aos sus pequeninos e túrgidos seios, e tanto corporizava estas imagens nascidas do seu amor, que todo o seu sistema nervoso se deixava dominar e vencer por elas o delíquio amoroso, ardente, abundante e violento (...) (GALLIS, s. d., p. 28-29).

Tamanha excitação sexual era, na verdade, um dos sintomas da doença de Maria Manuela. Como não podia satisfazer com o Luís as necessidades de seu corpo, e já que sua moral jamais permitiria que buscasse prazer com outros rapazes, Maria Manuela era tomada por delírios noturnos em que se entregava ao objeto de seu amor. Nesse sentido, Maria Manuela se configura como um claro exemplo de personagens naturalistas que, mesmo tentando manter as aparências em função da moral, são dominados intimamente pelos desejos do corpo, revelando um intenso conflito entre a carne e a racionalização a que deve se submeter na sociedade.

O estopim do martírio histérico de Maria Manuela foi ler a carta em que Luis terminava o namoro. Cobiçando um casamento que o beneficiasse financeira e socialmente, ele toma como noiva a viúva Isabel de Albergaria, dona de uma considerável fortuna. O impacto causado pela leitura da carta foi tão grande, que "um raio que tivesse caído próximo da pobre Maria Manuela não a teria deixado mais assombrada" (GALLIS, s. d., p. 58); a missiva "lhe escaldava as mãos e fazia refluir-lhe todo o sangue ao cérebro, dando-lhe na garganta um nó que a sufocava". Como uma histérica, Maria Manuela "soltou um grande grito e caiu no chão sem sentidos" (GALLIS, s. d., p. 59). A esse desmaio, seguiram os outros sintomas clássicos da patologia: prostração; perda de apetite; insônias; crises de choro; dores no corpo; e um angustiante fastio moral.

De todos esses sintomas, os mais críticos - e talvez os mais impactantes para os leitores da época - eram aqueles que manifestavam a incapacidade de frear o intenso desejo que consumia a jovem. Nas poucas vezes em que conseguia dormir, ela era atormentada por pesadelos voluptuosos em "que o seu temperamento ardente e sensual se expandia em manifestações eróticas advindas da grande fraqueza em que se encontrava" (GALLIS, s. d., p. 
60). O narrador informa que esses sonhos pioravam seu estado; os brometos "só conseguiram acalmar-lhe o estado nervoso, sem produzirem efeito na irritação sexual" (GALLIS, s. d., p. 60). Em outro momento, de maneira sutil, o narrador também menciona o sofrimento moral causado pela masturbação, chamada, de maneira suave, de o "toque próprio em alvos sensibilíssimos nos momentos das suas lavagens secretas" (GALLIS, s. d., p. 66).

Em diversos momentos do romance, o leitor é informado sobre histórias de jovens que permitiam certas "liberdades" aos namorados, não por conta do desejo sexual, mas para que fosse assegurado o casamento, já que "não há homens patifes; existem apenas mulheres tolas, desprovidas da arte de prender os homens, e nada mais" (GALLIS, s. d., p. 24). Essas moças faziam "tudo menos o resto" (GALLIS, s.d., p. 40), a fim de manter o interesse de seus pretendentes a marido. O comportamento dessas jovens em muito se enquadra no teor do proêmio, uma vez que, embora defenda o direito sexual da mulher, a única alternativa para tratar os sintomas da histeria era o matrimônio. De acordo com Verona, "no que tange à questão do histerismo, o coro dos doutores das páginas da ficção era uníssono: nem xarope de 'Easton', nem 'Pravaz', nem 'bromureto de potassium', o casamento era o melhor remédio" (VERONA, 2008, p. 7), algo que o "case-a, case-a" do Dr. Brilhante parece confirmar.

Embora o proêmio, à primeira vista, possa parecer que milita em favor da autonomia sexual da mulher casada ou solteira, em diversos momentos o narrador aparentemente reproduz o pensamento patriarcal a respeito do casamento, principalmente nas passagens em que acentua a teimosia de Maria Manuela em se manter virgem:

Uma mulher solteira e pobre à beira dos trinta é assim como que uma parvinha que nem impõe respeito às mocinhas nem merece as considerações das velhas. Naquela idade o têrmo solteirona é quase que uma deprimência social para a mulher, e tôdas coscuvilham com curiosidade malévola por que é que a mulher nestas condições se conserva celibatária quando outras mais pobres e mais feias se casam (GALLIS, s. d., p. 84)!

Maria Manuela, entretanto, se mostrava profundamente constrangida e escandalizada com o comportamento das amigas, já que acreditava na castidade do amor romântico. Ela chega a cogitar que teria sido mais fácil seguir o exemplo das amigas e procurar outros amores que pudessem curar sua carência de sexo, sentindo "raiva por Luís não a ter seduzido, apropriando-se da sua virgindade e dos ímpetos de seu grande amor" (GALLIS, s.d., p. 61), mas teme o azar de ser abandonada à maledicência. A histeria era uma claustrofobia incapacitante, pois, como declara Bulhões, obedecer às regras era sujeitar-se a "patologias, sofrimento, perversões e crimes sexuais" (BULHÕES, 2005, p. 8). 
A saúde de Maria Manuela atinge um ponto crítico: o útero começa a mostrar sinais de uma doença mais grave, causando uma piora também nos outros sintomas, levando-a a ter "grandes crises de choro seguidas de gritos estridentes, que eram como que a expansão de todos os seus nervos irritados" (GALLIS, s.d., p. 72). Por um tempo, Maria Manuela chega a esconder da mãe e do médico as dores que sentia nos ovários, além do corrimento vaginal, mas escondia, principalmente, "os repetidos espasmos venéreos que a dominavam, às vezes, sem mesmo um desejo sensual ou uma recordação dos seus amores" (GALLIS, s. d., p. 81).

Nesse ponto da narrativa, entra a figura do médico. Mesmo receitando "fortificantes, o ferro e a cola, uma alimentação forte e sadia e sobretudo a mudança de ares”, estava intimamente convencido de que "só a mudança de estado civil poderia operar a cura radical" (GALLIS, s. d., p. 81). Como o Autor no proêmio, o médico reconhecia que Maria Manuela "sofria apenas as consequências de sua virgindade forçada" (GALLIS, s. d., p. 82). Em decorrência de sua ida para o campo, essa clássica receita médica do século XIX, Maria Manuela passa a interagir com a outra mártir do romance, a Sra. Isidora, que também fora apaixonada por um Luís em sua juventude e acabou sua vida sofrendo do mesmo histerismo que acometia a moça. Juntas, Maria e Isidora se martirizam ao idealizar o que poderia ter sido de seus respectivos amores.

Mesmo depois de uma considerável melhora, o encontro com o Luis e Isabel, já casados, e a morte da amiga Isidora, são o ponto mais crítico do quadro de Maria:

[...] o médico suspeitava de carcinoma no útero. Não só as dores nesse delicado órgão se tinham tornado mais intensas, como o corrimento purulento aumentara a intensidade, por vêzes sanguíneo e com cheiro insuportável. O fastio era enorme, a elevação do ventre descomunal, e Maria passava as noites muito agitada. $\mathrm{O}$ fluxo menstrual tornara-se inconstante, por vêzes acompanhado de abundantes hemorragias. Os espasmos venéreos continuavam a dar-se com frequência, quase insensivelmente, num deplorável relaxamento das glândulas, num verdadeiro estado de blenorragia crônica, complicando com a blenometrite uterina. O médico que a tratava em Lisboa viera uma vez vê-la a pedido instante da D. Clementina, e declarara que só efetuando a operação vaginal, de maneira que o útero pudesse ser lavado com poderosos desinfetantes, é que havia meio de sustar a marcha progressiva, embora lenta, da doença (GALLIS, s. d., p. 138).

Mas a rapariga, herdeira do romantismo, "mesmo contra toda a racionalidade" (SANTANA, 2004, p. 242), resigna-se ao seu destino e recusa a operação vaginal que o médico prescrevera. O motivo da recusa? Maria Manuela "era virgem e queria levar para a cova essa virgindade que de nada lhe servia e da qual os homens da época atual pouco ou nenhum caso faziam, como sucedera ao Luís" (GALLIS, s. d., p. 138). Essa recusa faz com 
que a doença de Maria Manuela, passados sete meses no tempo da narrativa, passe a ser considerada incurável: "a invasão cancerosa apoderou-se de todo o útero atingindo os ligamentos e os ovários" (GALLIS, s. d., p. 156), e nem uma operação poderia curá-la.

Resignada à sua sina, Maria Manuela se entrega à doença na tentativa quixotesca de manter intacta a sua honra de virgem. Assim, o desfecho da história não poderia ser outro. Depois da pior crise que já tivera, Maria Manuela,

[...] agitando-se na cama, soltou um grito estridente:

- Luís!

Depois a cabeça descaiu-lhe para o lado, os braços penderam inertes, teve um ligeiro estremecimento e ficou quieta para nunca mais se mover.

Estava morta (GALLIS, s. d., p. 159)!

Depois de certificar o óbito, o médico, que em vários outros momentos se manifestara de maneira semelhante, afirma:

Toda a nossa a nossa ciência, minha senhora, é impotente para se antepor à força justa da natureza, e mais uma vez direi, o que já disse à senhora: o celibato forçado é um crime hediondo que produz milhares de vítimas. E neste gênero de crime que a hipocrisia social sanciona com a falsa máscara dum pudor que não sente, onde não há uma louca aparece um cadáver. Os hospitais de doidos e os cemitérios estão cheios de mulheres que perderam a razão ou morreram por não satisfazerem numa necessidade física a que têm direito todos os seres criados, ainda os mais humildes. [...] Contra a obra de Deus não há medicina possível e muito menos para aquela que se resume nesta simples fórmula: Crescei e multiplicai-os (GALLIS, s. d., p. 159-160).

Essa passagem, mais do que um eco da mensagem do proêmio, parece ter sido dita pela mesma "pessoa". Seria, talvez, o "médico" o verdadeiro autor do longo prefácio? Sim, se pensarmos no autor naturalista como aquele que assume o ponto de vista do médico ou do cientista ao tratar de seus personagens. Nessas palavras parece estar resumida toda a tese do romance, como se um círculo perfeito se completasse entre o proêmio e a narrativa. Numa primeira leitura do romance, parecia haver uma distância ideológica entre o proêmio a favor da liberação da mulher e uma narrativa que apresentava uma mulher completamente submissa à repressão de seus desejos. Uma leitura atenta revela, entretanto, que a histérica Maria Manuela, reprimida e ressentida, ilustra melhor a tese do romance do que uma mulher livre e liberada.

O drama de Maria Manuela é aumentado pela rigidez de seus princípios morais, que só a permitiriam desfrutar dos "prazeres da carne" caso se casasse, algo que ela necessitava "com a mesma ânsia com que precisava do ar que respirava" (GALLIS, s. d., p. 67); por outro lado, seu orgulho não permitia que ela se casasse com nenhum outro senão o Luís, a quem 
considerava seu primeiro e único amor. Contudo, apesar de todos os seus pudores, ela se mostra consciente - e, nesse sentido, ecoa o conteúdo do proêmio - de que era a necessidade de se manter irrepreensível diante da sociedade que a aprisionava em seu martírio, por causa dos "disfarces e hipocrisias que a mesma sociedade exige das mulheres solteiras para lhe passar atestado de honestas" (GALLIS, s. d., p. 67).

Ao contrário de Flaubert e Baudelaire, Gallis não precisou defender seus romances num tribunal, sejam aqueles assumidamente pornográficos, como aqueles publicados sob o pseudônimo "Rabelais", ou mesmo os de perfil naturalista. De antemão, o Autor informa ao leitor no proêmio que sua obra é fisiológica, não psicológica; que sua proposta é falar do corpo, das vontades da carne. Isso pode significar que, previamente alertado, o leitor deve despojar-se de suas prevenções morais, das barreiras impostas pelo convencionalismo. Isso é necessário porque, ao longo da narrativa, o leitor terá diante de si uma série de passagens de forte apelo sexual.

Assim, chegamos às passagens em que a histeria de Maria Manuela a leva sentir, fisicamente, os efeitos de um desejo sexual incontrolável. Imaginemos o escândalo causado pela leitura de um romance em que a protagonista tem orgasmos apenas com os beijos do namorado e que se masturba durante o banho. Imaginemos o impacto causado pela leitura de uma passagem em que uma jovem de reputação esmerada tem seu casto sono perturbado por sonhos eróticos com um homem que sequer era seu marido, ou que é tomada pelo "delíquio amoroso" apenas ao ouvir as aventuras conjugais de sua amiga. Assumindo o papel de leitor daquele tempo, não é difícil perceber como tais passagens podiam causar sensações no corpo de quem lia.

Ao mostrar com sua "pequena obra exclusivamente fisiológica" que os seres humanos estavam mais sujeitos à força da natureza do que às pressões sociais, Mártires da virgindade confirmava uma premissa do discurso pornográfico (HUNT, 1999). Sem querer criar rótulos que apenas limitam a compreensão do texto literário, ousamos dizer que esse texto específico de Gallis pertenceria a uma tradição pouco conhecida da literatura científica do final do século XIX chamada de "naturalismo pornográfico", aqui compreendendo a designação de pornográfico conforme o imaginário da época em que o romance foi escrito e lido. Ainda em construção, essa hipótese se torna possível por causa do grande número de obras naturalistas em que o tratamento científico-literário da sexualidade as transformava em pornografia aos olhos dos leitores do século XIX (EL FAR, 2004; MENDES, 2014). 


\section{Considerações finais}

Não cabe dizer qual era a intenção do autor ao escrever Mártires da virgindade, um estudo quase clínico sobre o celibato forçado da mulher. Também não conhecemos completamente a recepção do público sobre essas passagens, ora de uma sexualidade apenas sugerida, ora mais pronunciada, mesmo porque, apesar de tentarmos, jamais conseguiríamos adotar, em sua totalidade, o ponto de vista do leitor oitocentista. Todavia, podemos imaginar que, numa sociedade patriarcal e controladora, a simples escolha do tema da sexualidade feminina tenha confirmado, diante da crítica e do fetiche de leitores sem outros canais de satisfação do desejo, o objetivo pornográfico da narrativa.

Por outro lado, também sabemos que a problematização da sexualidade feminina era constantemente colocada em foco não com o objetivo de problematizar e propor melhorias em favor daquelas que sempre foram tratadas com um misto de atração e repulsa, mas para manter a hegemonia masculina sobre o corpo e o desejo femininos, o que traz à tona o propalado objetivo pedagógico do naturalismo.

Assim, não podemos afirmar com certeza que o final trágico que aguardava as histéricas era um alerta pedagógico ou uma denúncia da opressão a que eram submetidas as mulheres daquele tempo. Pedagógicas ou pornográficas, essas teses em forma de romance tinham como objetivo "chibar", isto é, denunciar as torpezas que a hipocrisia burguesa tentava esconder. Reconhecendo a inconclusividade desse estudo, que ainda pode nos oferecer muito material de pesquisa, que seja finalmente ouvido, mais de um século depois, o grito desse esquecido escritor português: “Abaixo, pois, a tirania social que decreta a virgindade forçada da mulher solteira" (GALLIS, s. d., p. 18)!

\section{Referências bibliográficas:}

BULHÕES, Marcelo. Histeria, sedução e frustração: o erotismo em romances naturalistas brasileiros. Cadernos Neolatinos. Rio de Janeiro: Departamento de Letras Neolatinas; Faculdade de Letras da UFRJ, ano IV (número especial), abr. de 2005.

CATHARINA, Pedro Paulo Garcia Ferreira. De "O Artigo 200" a "O aborto": trajetória de um romance naturalista. Letras. Santa Maria: Universidade Federal de Santa Maria, vol. 23, n. 47, p. 37-58, jul.-dez 2013.

EL FAR, Alessandra. Páginas de sensação: literatura popular e pornográfica no Rio de Janeiro (1870-1924). São Paulo: Cia. das Letras, 2004. 
GALLIS, Alfredo. Mártires da virgindade. São Paulo: Edições Júpiter, s.d.

HUNT, Lynn. Introdução: obscenidade e as origens da modernidade, 1500-1800. In:

(Org.). A invenção da pornografia: obscenidade e as origens da modernidade. São Paulo: Hedra, 1999, p. 9-46.

JESUS, Maria Saraiva. Alguns estereótipos sobre a mulher na segunda metade do século XIX. Veredas, Porto, n. 1, p. 149-163, 1998. Disponível em: https://digitalis.uc.pt/ptpt/artigo/alguns_estere\%C3\%B3tipos_sobre_mulher_na_segunda_metade_do_s\%C3\%A9cul o_xix. Acesso em: 5 jun. 2015.

LEÃO, Andréa Borges. Brasil em imaginação: livros, impressos e leituras infantis (1890 1915). Fortaleza: INESP, UFC, 2012.

MAINGUENEAU, Dominique. Uma categoria problemática. In: __. O discurso pornográfico. São Paulo: Parábola Editorial, 2010, p. 13-37.

MENDES, Leonardo. Biblioteca picante: o naturalismo como produto erótico. In: HELENA, Lucia; OLIVEIRA, Paulo César de (Orgs.). Literatura, arte e mercado: XI Seminário NaçãoInvenção. Niterói, RJ: Instituto de Letras da Universidade Federal Fluminense, 2014, p. 8395.

PIMENTEL, Figueiredo. O aborto. Org. Leonardo Mendes; Pedro Paulo Garcia Ferreira Catharina. Rio de Janeiro: 7Letras, 2015 [1893].

RANGEL, Maria Beatriz de Souza. Histeria e feminilidade. Rio de Janeiro: Universidade Veiga de Almeida, 2008, 108 f. Dissertação. Mestrado Profissional em Psicanálise, Saúde e Sociedade.

SANTANA, Maria Helena. Pornografia no fim do século: os romances de Alfredo Gallis. Portuguese Literary and Cultural Studies, n. 12, p. 235-248, 2004.

VENTURA, Antônio. Rabelais, isto é, Alfredo Gallis, o pornógrafo. In: GALLIS, Alfredo. Aventuras galantes. Lisboa: Edições Tinta da China, 2011, p. 167-174.

VERONA, Elisa Maria. O romance, a mulher e o histerismo no século XIX brasileiro. Histórica - Revista Eletrônica do Arquivo Público do Estado de São Paulo. São Paulo, n. 32, p. 1-8, 2008.

\section{Naturalism, pornography and hysteria in Mártires da virgindade, by Alfredo Gallis}

Abstract: This article aims at reading the work Mártires da virgindade [Martyrs of virginity] (c.1900), by Joaquim Alfredo Gallis (1859-1910), in order to explore the subject of hysteria in naturalist literature. In order to substantiate our analysis, we discuss how pornography and naturalist fiction got mixed up at the turn of the century, because sex, amidst positivist 
controversy, seemed to be a cause of physic and mental ills - the so-called "social pathologies" of society at the time.

Keywords: Alfredo Gallis. Martyrs of virginity. Naturalism. Pornography. Hysteria.

Recebido em: 12 de setembro de 2015 .

Aprovado em: 22 de dezembro de 2015. 